\title{
WPS4583
}

\author{
Policy Research Working Paper 4583
}

\section{The Demographic, Economic and Financial Determinants of International Remittances in Developing Countries}

\author{
Richard H. Adams, Jr.
}

The World Bank

Development Economics Department

Development Prospects Group

March 2008 
Policy Research Working Paper 4583

\begin{abstract}
What causes developing countries to receive different levels of international remittances? This paper addresses this question by using new data on such variables as the skill composition of migrants, poverty, and interest and exchange rates to examine the determinants of remittances. The paper finds that the skill composition of migrants does matter in remittance determination.
\end{abstract}

Countries which export a larger share of high-skilled (educated) migrants receive less per capita remittances than countries which export a larger proportion of lowskilled migrants. It also finds that the level of poverty in a labor-sending country does not have a positive impact on the level of remittances received.

This paper-a product of the Development Prospects Group, Development Economics Department—is part of a larger effort to understand the determinants of international remittances in the developing world. Policy Research Working Papers are also posted on the Web at http://econ.worldbank.org. The author may be contacted at radams@worldbank.org.

The Policy Research Working Paper Series disseminates the findings of work in progress to encourage the exchange of ideas about development issues. An objective of the series is to get the findings out quickly, even if the presentations are less than fully polished. The papers carry the names of the authors and should be cited accordingly. The findings, interpretations, and conclusions expressed in this paper are entirely those of the authors. They do not necessarily represent the views of the International Bank for Reconstruction and Development/World Bank and its affiliated organizations, or those of the Executive Directors of the World Bank or the governments they represent. 


\title{
The Demographic, Economic and Financial Determinants of International Remittances in Developing Countries
}

\author{
Richard H. Adams, Jr. ${ }^{1}$
}

Keywords: International remittances, migration, poverty, skill composition of migrants

\footnotetext{
${ }^{1}$ Development Prospects Group, The World Bank, Washington, DC. radams@worldbank.org
} 


\section{$\underline{\text { Acknowledgements }}$}

*I would like to thank Maurice Schiff, Çaglar Özden and several anonymous reviewers for useful comments on earlier drafts. 
International remittances refer to the money and goods that are transmitted to households by migrant workers working outside of their origin countries. At the start of the $21^{\text {st }}$ Century these resource transfers represent one of the key issues in economic development. In 2004 official international remittances were estimated at \$93 billion per year (Ratha, 2004), ${ }^{1}$ making them about twice as large as the level of official aid-related flows to developing countries.

Despite the ever-increasing size of official international remittances, relatively little attention has been paid to the demographic, economic and financial determinants of these resource flows at the country level. The basic question here is simple: What causes different developing countries to receive different levels of remittances? What is the impact of such factors as the skill composition of migrants and the level of poverty in labor-sending countries on the amount of international remittances received? At the same time, how do economic, financial and political factors - like level of country income, interest rates and exchange rates -- affect the level of remittances received by countries?

This paper proposes to answer these, and similar, questions using a new data set composed of 76 developing countries. This data set includes all those labor-sending countries for which reasonable information on the skill composition of migrants, poverty, remittances and other financial and political factors could be assembled. The data set includes countries drawn from each major region of the developing world: Latin 
America and the Caribbean, Middle East and North Africa, Europe and Central Asia, East Asia, Sub-Saharan Africa and South Asia.

The balance of this paper is organized as follows. Section 2 sets the stage by reviewing the findings of recent studies on the demographic, economic and financial determinants of international remittances. Section 3 presents the new data set, and Section 4 uses the new data to econometrically examine the determinants of remittances. To control for possible endogenity bias, this section employs an instrumental variables (IV) strategy to isolate the overall relationship between remittances, the skill level of migration, migration stock and poverty. Controlling for all other factors, this approach finds that high-skilled migrants tend to remit less to labor-sending countries, and that low-skilled migrants tend to remit more. The final section, Section 5, summarizes the findings.

\section{Recent Studies on the Determinants of International Remittances}

Two approaches dominate the recent literature on the determinants of international remittances: one approach focusing on microeconomic variables, and the other focusing on more macroeconomic factors. At the microeconomic level, Lucas and Stark (1985) were the first to elaborate a formal model for analyzing the remittances of migrant workers. These authors hypothesized that migrant workers are motivated to remit for a variety of reasons, ranging from pure altruism to pure self-interest. According to Lucas and Stark (1985), migrant workers can be classified as altruistic if their remittances increase with declines in family income at home, while self-interest motives would be considered dominant if remittances were positively related with family income 
at home. Recent efforts to test the altruistic vs. self-interest hypothesis with respect to remittances at the micro-economic level include Agarwal and Horowitz (2002), Foster and Rosenzweig (2001) and Ilahi and Jafarey (1999).

At the same time, other researchers have used aggregate data to analyze the macroeconomic factors that affect the behavior of remitters. These researchers have suggested that macroeconomic factors - like interest rates, exchange rates and political instability - all have an impact on the level of international remittances received by countries (Higgins et al, 2004, El-Sakka and McNabb, 1999; Glytsos, 1997; and Faini, 1994). These analysts typically find that interest and exchange rates need to be competitive and that countries need to be politically stable in order encourage the flow of remittances to labor-sending countries.

The analysis pursued in this paper attempts to combine the microeconomic and macroeconomic approaches to remittance determination by doing two things. First, the analysis adds a new (and important) variable into the modeling effort: poverty. Because of the lack of poverty data for many developing countries, no past study has attempted to analyze how the level of poverty in a labor-sending country affects the level of international remittances received. On the one hand, since remittances are largely individual transfers, made from a migrant to his family back home, it might be argued that the poverty of the household is a more important determinant of remittances than the poverty of the country. However, since the poverty data used in this paper is based on the results of nationally-representative household surveys in particular labor-sending countries; such data represents a useful means for identifying how country-level poverty affects the level of international remittances received by countries. If, for example, 
migrant workers are altruistic, more country-level poverty at home should encourage them to remit more money.

Second, this paper uses macro-economic data on the skill composition of migrants to examine how the type of workers sent abroad by a country - educated or uneducated, skilled or unskilled - affects the level of remittances received by that country. Until recently, the lack of country-level data on the skill composition of migrants has prevented much meaningful work on this issue. ${ }^{2}$ At the micro-economic level, some past studies have suggested that (holding all other factors constant) more educated migrants remit more because they typically earn more (Banerjee, 1984). However, other microeconomic studies have found that more educated migrants remit less because they have lower propensities to return to their origin country (Rapoport and Docquier, 2004). Using country-level data on the skill composition of migrants can help clarify which of these predictions is correct.

\section{New Data on the Determinants of International Remittances}

As noted above, this study is based on a new data set that includes information on remittances, poverty, country income, the skill level of migrants and other economic and financial variables for 76 "low-income and middle-income” developing countries. ${ }^{3}$ These countries were selected because it was possible to find relevant data on all of these variables for the period 1995 to 2001. Since it was not easy to assemble this data set, and several problems still plague this (and all other) data sets on international remittances, it is important to spell out how this information was assembled. 
The data on international remittances in this paper come from the International Monetary Fund (IMF) publication, Balance of Payments Statistics Yearbook. This publication records the annual amount of international remittances received by each labor-sending country. ${ }^{4}$ However, it should be emphasized that these IMF records are incomplete because they only include data on official international remittance flows, that is, remittance monies which are transmitted through official banking channels. In virtually every labor-sending country a large (and unknown) proportion of remittance monies is transmitted through private, unrecorded channels. These private transfers include remittances brought home by friends, relatives and even the migrant himself. As a result, the level of international remittances recorded by the IMF significantly underestimates the actual flow of remittances (official and unofficial) returning to laborsending countries. ${ }^{5}$

All of the poverty data used in this paper comes from the results of nationallyrepresentative household budget surveys, as recorded on the World Bank website, $\underline{\text { Povcal }}$ Net. One of the problems with these poverty data is that many developing countries have not conducted the type of household budget surveys needed to produce reliable poverty figures. For example, of the 157 developing countries classified as low- or middleincome by the World Bank, ${ }^{6}$ only 81 countries (52\%) have published the results of any household budget survey. Of these 81 countries, missing data on international remittances reduced the sample used here to 76 . However, not all of these 76 countries conducted household surveys in the year 2000, which is the year for which all the data on the skill composition of migrants are available (see below). As a result, all the poverty data used in this study comes from that single household survey which was done closest 
to the year 2000 during the 6-year period, 1995 to 2001. Countries which did household surveys before 1995 are not included in the data set.

With respect to the skill composition of migrants, few (if any) of the developing countries in the world publish accurate records on the number of international migrants that they produce. It is therefore necessary to estimate migration information by using data collected in the main labor-receiving countries of the world. For the purposes of this paper, the main labor-receiving countries (regions) include two: OECD (America), including United States and Canada; and OECD (Europe), excluding America and Asia. ${ }^{7}$ Unfortunately, no data are available on the level of worker migration to the third most important labor-receiving region in the world, the Persian Gulf. This is unfortunate because large numbers of workers from the Middle East and South Asia go to work in the Persian Gulf.

In the past there has been a lack of disaggregated data on the skill composition of migrant stocks and flows. However, a new data set compiled by Docquier and Marfouk (2005) classifies international migrants from each country according to their level of educational attainment: low-skilled (less than 8 years of schooling); medium-skilled (9 to 12 years of schooling); and high-skilled (13 years or more of schooling). This data set, which is based on population census and register data from nearly every OECD country, counts as international migrants all those who are "foreign born" and of working age (25 years and over), who are living in either the OECD (America) or OECD (Europe).

This paper uses the Docquier and Marfouk (2005) data to analyze how the skill (educational) level of migrants from different developing countries affects the flow of international remittances to these countries. However, like all data sets on international 
migration, the Docquier and Marfouk (2005) data contain several important limitations. Most notably, by focusing on information collected from census and register data, these data do not capture the very large number of illegal and irregular migrants living and working in the OECD. For example, in 2002 the stock of illegal immigrants in the United States was estimated at 9.3 million, or about 26 percent of the total stock of the “foreign-born” population in the United States (Passel, Capps, and Fix, 2004). Since it focuses on OECD countries, the Docquier and Marfouk (2005) data also do not include the large number of migrants from the Middle East and South Asia who are currently working in the Persian Gulf. In 2000 the total stock of migrants working in the Persian Gulf was estimated at 9.6 million. Finally, the Docquier and Marfouk (2005) data only relate to the stock of migrants, not flows of migrants. In other words, these data only provide information on the numbers of migrants currently living and working in the OECD, and not on the flows of migrants going to (and returning from) the OECD. ${ }^{8}$

Appendix Table 1 shows the countries, poverty, international remittance and skill composition of migrant variables included in the new data set. The data set includes one observation for each of the 76 countries and is notable in that it includes 14 observations for Sub-Saharan Africa, a region for which poverty, remittances and skill composition of migrant data are relatively rare.

- Put Appendix Table 1 at end of paper -

Appendix Table 1 reports two different poverty measures. The first, the headcount index, set at \$1 per person per day, measures the percent of the population living beneath that poverty line at the time of the household budget survey. ${ }^{9}$ However, the headcount index ignores the "depth of poverty," that is, the amount by which the 
average expenditures (income) of the poor fall short of the poverty line. ${ }^{10}$ The table therefore also reports the poverty gap index, which measures in percentage terms how far the average expenditures (income) of the poor fall short of the poverty line. For instance, a poverty gap of 10 percent means that the average poor person's expenditures (income) are 90 percent of the poverty line.

The remaining data for this study are defined as follows.

In the literature income is often found to be an important determinant of remittances. In micro-economic studies, income is typically measured in terms of both the migrant's income abroad and the income of his family back home (e.g. Faini, 1994; Lucas and Stark, 1985); in macro-economic studies, this variable is usually measured by the GDP income of the labor-sending country (e.g. Glytsos, 1997). While microeconomic studies tend to find that family income back home has a positive and significant effect on the level of remittances sent home (Lucas and Stark, 1985; Cox, Eser and Jimenez, 1998), in macro-economic studies the impact of this variable is often unclear. To clarify the impact of income on the determination of remittances, this study includes data on the per capita GDP income (and its square) in the labor-sending country. ${ }^{11}$

The distribution of income in the labor-sending country may also affect the flow of remittances. This study therefore includes data on the Gini coefficient, which is normalized by household size.

The next two variables in this study - percentage of population under age 14 and real interest rate in origin country - provide another way for examining the determinants of remittances. ${ }^{12}$ Since both countries and families tend to be needier when they have a 
higher proportion of young dependents, it is likely that countries with a higher proportion of people under age 14 will receive more remittances. At the same time, if migrants are motivated by investment returns at home, then the variable measuring the real interest rate should have a positive and significant impact on the receipt of remittances. Several macro-economic studies have found that migrants tend to remit more money when interest rates at home are high and positive (El-Sakka and McNabb, 1999; Lianos, 1997). ${ }^{13}$

Finally, with respect to financial and political variables, various studies have suggested that factors like the costs of remitting money home, exchange rate spread and the presence of civil unrest may act as determinants of remittances (Freund and Spatafora, 2005; Higgins et al, 2004). For example, it has been suggested that as the costs of remitting money through official channels rise, and the spread between the exchange rates offered by remitting agencies and the central exchange increase, then the amount of remittance monies will fall. Similarly, it has been argued that political or civil unrest in the country of origin will also cause the amount of remittances to decline. To test the impact of these factors, this study includes the following 3 variables: (1) the costs of remitting US \$200 to a labor-sending country; (2) the implicit exchange rate spread (defined as the difference between the exchange rate offered by remittance agencies and the central exchange rate as quoted by Bloomberg); and (3) the presence of civil war in a labor-sending country (1 if yes, otherwise zero). ${ }^{14}$ 


\section{Country-level Determinants of International Remittances: IV Results}

In this section the new data are used to analyze the determinants of international remittances at the country level. The basic relationship that we want to analyze can be written as:

$$
\begin{gathered}
\log \mathrm{R}_{i}=\alpha+\beta_{1} \log \gamma_{i}+\beta_{2} \log \mu_{i}+\beta_{3} \log \mathrm{x}_{i}+\varepsilon_{i} \\
(i=1, \ldots, \mathrm{N})
\end{gathered}
$$

Where $\mathrm{R}$ is the measure of per capita international remittances received by country $i, \alpha$ is a fixed-effect reflecting unobservable differences between countries, $\gamma_{i}, \mu_{i}$, and $\mathrm{x}_{i}$ are a set of demographic, economic and financial/political characteristics, respectively, for country $i$, and $\varepsilon$ is an error term.

The various remittance, demographic, economic and financial variables for estimating equation (1) have already been identified and discussed. Since all of these variables (except the “war” variable) are estimated in log terms, the results can be interpreted as elasticities of remittances with respect to the relevant variable.

Equation (1) can be estimated using ordinary least squares (OLS). However, it is possible that several of the right-hand side variables in the model - including those for the skill level of migration, the stock of migrants and poverty - may be endogenous to remittances. Reverse causality may be taking place: remittances may be affecting the skill level of migration, the stock of migrants abroad and poverty in the labor-sending country. Using OLS to estimate equation (1) would therefore lead to biased results.

One possible solution to these problems would be to use panel data to estimate equation (1). Panel data, which includes repeated observations on the same unit (e.g. country, household) over two or more time periods, is a good solution because by taking “first differences” between various variables it becomes possible to eliminate many of the 
biases that arise from endogeneity and omitted variables. Unfortunately, however, panel data sets on international migration and remittances in the developing world are relatively rare, and there are no panel data available to estimate equation (1).

Since we are working with cross-section data, one possible way of estimating equation (1) is to use instrumental variables. A good instrumental variable, one that is correlated with the explanatory variable but uncorrelated with the outcome variable, can eliminate many of the biases that arise from endogenous variables. ${ }^{15}$

The balance of this section will pursue an instrumental variables approach to estimating equation (1). ${ }^{16}$ The challenge here is to find good instrumental variables for the three possible endogenous regressors in the model: (1) the skill level of migrants; (2) the stock of migrants abroad; and (3) poverty. ${ }^{17}$ Choosing instrumental variables for these regressors, and testing for the relevance of these instruments, can be done as follows.

With respect to the skill level of migrants, two possible instruments exist in our data set. The first instrument is distance (miles) between the labor-sending country and the main remittance-sending region (US, OECD (Europe) or the Persian Gulf). ${ }^{18}$ This variable seems like a good instrument because distance affects the skill level of migration: holding other factors constant, labor-sending countries which are located closer to main remittance-sending regions (e.g. Mexico and the US) seem more likely to send a higher proportion of low-skilled migrants, because the costs of migration are lower. A second instrument for the skill level of migrants is language. Here we would expect that if the labor-sending country speaks the same language as the main remittancesending region, then there would be a higher proportion of high-skilled migration. 
With respect to the stock of migrants abroad, three possible instruments exist: total population in the labor-sending country, population density in the labor-sending country and the percent of the urban population in the labor-sending country. Holding all other factors constant, it is expected that all three of these variables will be positively related with the stock of migrants abroad.

For the two poverty variables (poverty headcount and poverty gap), one possible instrument is the percentage of the population living in urban areas in the labor-sending country. Since poverty in many developing countries is often concentrated in rural areas, ceteris paribus, it is expected that countries with a higher percentage of people living in urban areas would have less poverty. ${ }^{19}$

Tables 1-3 present the first-stage results for the three instrumented variables. In Table 1 the two instrumental variables are significant, and the p-values for the Fstatistic of the excluded instruments are less than 0.01 for the prediction of low-skilled migration and the F-statistics themselves are over 17. These results suggest instrument relevance. In Table 2 two of the three instrumental variables are highly significant, and when the three variables are combined together (equation (4) in Table 2), the F-statistics are over 27 . In Table 3 the instrumental variables are statistically significant for each of the poverty variables, and the F-statistics for each equation are over 39. These results suggest instrument relevance.

- Put Tables 1, 2 and 3 Here -

Tables 4 and 5 present the second-stage IV results. Table 4 shows results when the skill composition of migrants is low-skilled (less than 8 years of schooling), while Table 5 shows results when migrants are high-skilled (13 or more years of schooling). In 
each table columns (1-2) show results for the instrumented skill level of migration variable, columns (3-4) show results for the instrumented stock of migrants' variable, and columns (5-6) show the results for the instrumented poverty variable. In each table the overidentification test p-values (for the Hansen J-statistic) are larger than 0.10 for all specifications of instrument sets A and B, so we cannot reject that our instruments are valid.

- Put Tables 4 and 5 Here -

The IV results for low-skilled migrants in Table 4 reveal five key findings. First, the level of poverty in a labor-sending country has no statistical effect on the amount of per capita remittances received by a country. In Table 4 all of the coefficients for the instrumented poverty variables are statistically insignificant. Second, ceteris paribus, countries which export a larger share of low-skilled migrants receive more remittances per capita. The Table 4 results suggest that a 10 percent increase in the share of lowskilled migrants from a labor-sending country will increase the amount of per capita remittances received by a country by between 9.1 and 19.8 percent. Third, the level of per capita remittances received by a country is positively related to investment returns at home. All of the coefficients for the real interest rate variable in Table 4 are positive and significant. Fourth, holding all other factors constant, an inverted U-shaped curve seems to exist between the level of country GDP income and the receipt of remittances. ${ }^{20}$ Four of the six coefficients for per capita GDP income variable are positive and significant, and three of the coefficients for the square of this term are negative and significant. Finally, the amount of per capita remittances received by a country seems to be positively 
related to the proportion of young dependents at home. Four of the six coefficients for the variable "percent of population under 14 years" are positive and significant.

The IV results for high-skilled migrants in Table 5 can be examined with respect to the same five findings. On poverty, four of the six coefficients for the instrumented poverty variable are negative and significant. This suggests that for high-skilled migrants poverty does have an impact on the flow of remittances and that more poverty in a laborsending country actually leads to less per capita remittances. More work, possibly on a broader set of countries, is needed to identify the reasons for this outcome. With respect to the skill level of migration, Table 5 shows that high-skilled migrants remit less to labor-sending countries. Holding all other factors constant, a 10 percent increase in the share of high-skilled migrants from a labor-sending country will reduce the amount of per capita remittances received by a country by between 11.2 and 19.7 percent. On interest rates, the level of per capita remittances seems to be positively related to investment returns at home. Just as in Table 4, all of the coefficients for the real interest rate variable are positive and significant, and of roughly the same magnitude as those in Table 4. On the relationship between country income and remittances, most - but not all - of the coefficients in Table 5 suggest that an inverted-U shaped curve exists between the level of per capita GDP income in a country and the receipt of remittances. Like the previous table, these results suggest that middle-income countries receive more per capita remittances than low- or high-income countries. Finally, the amount of per capita remittances received by a country seems to be positively related to the proportion of young dependents at home. In Table 5 four of the six coefficients for the variable "percent of population under 14 years" are positive and significant. 


\section{Conclusions}

This paper has used new data from 76 low- and middle-income developing countries to examine the demographic, economic and financial determinants of international remittances. Four main conclusions emerge.

First, the econometric results presented here suggest that the skill composition of migrants does matter in remittance determination: ceteris paribus, countries which export a larger share of high-skilled (educated) migrants receive less per capita remittances than countries which export a larger proportion of low-skilled migrants. Instrumental variable results suggest that a 10 percent increase in the share of high-skilled migrants from a labor-sending country will reduce the amount of per capita remittances received by a county by 11.2 to 19.7 percent, while a similar 10 percent increase in the share of low-skilled migrants will increase the level of remittances received by 9.1 to 19.8 percent. Although the country-level data presented here cannot provide a definitive explanation for these outcomes, one possible explanation is that high-skilled migrants remit less because they are more likely to bring family members and to remain in their newly adopted country, ${ }^{21}$ and so they are less concerned with any eventual return to their home country. By contrast, low-skilled migrants tend to remit more because their migration is more temporary in nature and they are more concerned with returning home.

Second, the level of poverty in the labor-sending country does not have a positive impact on the amount of remittances received by a country. For low-skilled migrants, the level of poverty in a country - defined either in terms of the level or depth of poverty has no statistically significant effect on the amount of remittances received. For highskilled migrants, holding all other factors constant, the level of poverty in a country 
actually has a negative and significant impact on the amount of remittances received. Although the country-level data presented here cannot fully explain this outcome, one possible reason is that high-skilled migrants may remit more on the basis of investment opportunities at home.

The third conclusion follows from the preceding, namely, that the level of per capita remittances received by a country is positively related to investment returns at home. In all versions of the remittance model presented here, all of the coefficients measuring real interest rates at home are positively and significantly related to the level of per capita remittances received by a country. In this study, countries with more competitive real interest rates receive more per capita remittances.

The final conclusion is that most - but not all -- of the results presented here suggest that an inverted-U shaped curve exists between the level of per capita GDP income in a country and the receipt of remittances. With all other factors held constant, the level of per capita remittances received by a country increases until a country has a per capita GDP income of about $\$ 2,200$ per year, and falls thereafter. In other words, middle-income countries receive more per capita remittances than low- or high-income countries. More work is needed to see if this finding holds for a broader selection of labor-sending countries. 
Table 1. First-stage IV estimates for percent of low-skilled migrants (less than 8 years of schooling) in total migrants from labor-sending country

(1)

-0.148
$(-2.55)$

Distance from labor-sending country to main remittance-

sending region (US, OECD (Europe) or Persian Gulf)

Language (1 if same language in labor-sending country and

main remittance-sending region)

Included exogenous variables

Poverty headcount in labor-sending country

(\$1.08/person/day)

Stock of total migrants from labor-sending country in OECD

Percent of population under 14 years in labor-sending

country

Per capita GDP in labor-sending country (constant 2000

dollars)

Per capita GDP squared

Gini coefficient in labor-sending country

Real interest rate (percent) in labor-sending country

Cost to send $\$ 200$ remittances to country

Exchange rate spread in labor-sending country

War in labor-sending country (dummy)

Constant

$\mathrm{N}$

$\mathrm{R}^{2}$

F-statistic, excluded instruments

P-value

$-0.046$

$(-0.73)$

0.067

(1.45)

0.059

(0.15)

0.156

(0.14)

$-0.023$

$(-0.31)$

0.113

(0.25)

$-0.129$

$(-1.88)$

0.329

(1.30)

0.030

(0.56)

0.123

(0.87)

3.034

$(0.70)$

62

0.438

17.37

0.000
(2)

(3)

$-0.119$

$(-2.20)^{*}$

$-0.820$

$\begin{array}{ll}-0.843 & -0.820 \\ (-6.88)^{* *} & (-6.97)^{* *}\end{array}$

$\begin{array}{ll}-0.023 & -0.025\end{array}$

$(-0.51) \quad(-0.62)$

$0.127 \quad 0.109$

$(3.85)^{* *} \quad(3.25)^{* *}$

$0.366 \quad 0.329$

(1.24) (1.04)

$0.385-0.350$

$\begin{array}{ll}0.47) & (0.43)\end{array}$

$-0.031 \quad-0.032$

$(-0.55) \quad(-0.57)$

$-0.365 \quad-0.180$

$(-1.01) \quad(-0.47)$

$-0.114 \quad-0.118$

$(-1.97) \quad(-2.25)^{*}$

$0.066 \quad 0.102$

$(0.35) \quad(0.53)$

$0.018 \quad 0.019$

$(0.46) \quad(0.48)$

$0.073 \quad 0.072$

$(0.51) \quad(0.56)$

$\begin{array}{ll}-0.447 & 1.083 \\ (-0.17) & (0.38)\end{array}$

$(-0.17) \quad(0.38)$

$62 \quad 62$

$\begin{array}{ll}0.640 & 0.668\end{array}$

$18.73 \quad 23.49$

$0.000 \quad 0.000$

Notes: All variables expressed in logs; all equations include 5 regional dummy variables which are not reported here. Robust t-statistics shown in parentheses. Number of observations reduced in table because of missing values for certain variables. See Appendix Table 1 for countries and survey dates.

* Significant at the 0.05 level $\quad * *$ Significant at the 0.01 level 
Table 2. First-stage IV estimates for stock of total migrants from labor-sending country in OECD

Instruments

Total population in labor-sending country

Population density in labor-sending country

Percent urban population in labor-sending country

Included exogenous variables

Percent of low-skilled migrants (less than 8 years schooling)

in total migrants from labor-sending country in OECD

Poverty headcount in labor-sending country

(\$1.08/person/day)

Percent of population under 14 years in labor-sending country

Per capita GDP in labor-sending country (constant 2000 dollars)

Per capita GDP squared

Gini coefficient in labor-sending country

Real interest rate (percent) in labor-sending country

Cost to send $\$ 200$ remittances to country

Exchange rate spread in labor-sending country

War in labor-sending country (dummy)

Constant

$\mathrm{N}$
$\mathrm{R}^{2}$

F-statistic, excluded instruments

P-value
(1) (2)

0.682
$(5.70)^{* *}$

(3)

(4)

0.665

$(6.71)^{* *}$

0.627

$(4.49)^{* *}$

$(2.85)^{* *}$

$-0.503$

0.443

$(-0.60)$

(0.93)

\begin{tabular}{cc}
0.761 & 0.374 \\
$(2.41)^{*}$ & $(0.88)$ \\
0.102 & 0.262 \\
$(0.58)$ & $(1.35)$ \\
-0.994 & -0.834 \\
$(-1.19)$ & $(-0.77)$ \\
3.632 & 5.044 \\
$(1.62)$ & $(1.48)$ \\
-0.209 & -0.306 \\
$(-1.33)$ & $(-1.25)$ \\
-0.376 & -2.684 \\
$(-0.32)$ & $(-2.02)^{*}$ \\
0.134 & -0.110 \\
$(0.78)$ & $(-0.59)$ \\
0.318 & -0.101 \\
$(0.51)$ & $(-0.11)$ \\
0.051 & 0.195 \\
$(0.50)$ & $(1.51)$ \\
0.402 & 0.712 \\
$(1.03)$ & $(1.96)$ \\
-5.894 & -11.225 \\
$(-0.67)$ & $(-0.92)$ \\
62 & 53 \\
0.691 & 0.610 \\
28.77 & 11.30 \\
0.000 & 0.001 \\
$d u m m y$ & $a r e .10 t$ \\
\hline
\end{tabular}

0.684

(1.92)*

0.158

(0.79)

$-1.542$

(-1.23)

4.775

(1.68)

$-0.281$

$(-1.44)$

$-0.790$

(-0.58)

$-0.076$

(-0.36)

$-0.113$

(-0.11)

0.148

(1.23)

0.752

(1.57)

$-3.315$

(-0.30)

62

0.477

8.00

0.006

0.287

(1.01)

0.066

(0.49)

$-0.580$

$(-0.78)$

3.265

(1.26)

$-0.198$

$(-1.10)$

$-0.788$

$(-0.77)$

$-0.004$

(-0.03)

0.134

(0.21)

0.082

(0.92)

0.314

(0.89)

$-7.373$

(-0.82)

53

0.811

27.90

0.000

Notes: All variables expressed in logs; all equations include 5 regional dummy variables which are not reported here. Robust t-statistics shown in parentheses. Number of observations reduced in table because of missing values for certain variables. See Appendix Table 1 for countries and survey dates.

\footnotetext{
* Significant at the 0.05 level $\quad * *$ Significant at the 0.01 level
} 
Table 3. First-stage IV estimates for poverty headcount (\$1.08/person/day) and poverty gap

\begin{tabular}{|c|c|c|}
\hline & $\begin{array}{l}\text { Poverty headcount } \\
\text { (1) }\end{array}$ & $\begin{array}{c}\text { Poverty gap } \\
(2)\end{array}$ \\
\hline \multicolumn{3}{|l|}{ Instruments } \\
\hline Percent urban population in labor-sending country & $\begin{array}{l}0.979 \\
(2.11)^{*}\end{array}$ & $\begin{array}{c}1.442 \\
(2.75)^{*}\end{array}$ \\
\hline \multicolumn{3}{|l|}{ Included exogenous variables } \\
\hline $\begin{array}{l}\text { Percent of low-skilled migrants (less than } 8 \text { years schooling) in } \\
\text { total migrants from labor-sending country in OECD }\end{array}$ & $\begin{array}{l}-0.087 \\
(-0.31)\end{array}$ & $\begin{array}{l}-0.057 \\
(-0.17)\end{array}$ \\
\hline Stock of total migrants from labor-sending country in OECD & $\begin{array}{r}0.078 \\
(0.73)\end{array}$ & $\begin{array}{r}0.092 \\
(0.71)\end{array}$ \\
\hline Percent of population under 14 years in labor-sending country & $\begin{array}{l}-0.057 \\
(-0.05)\end{array}$ & $\begin{array}{l}-0.723 \\
(-0.63)\end{array}$ \\
\hline Per capita GDP in labor-sending country (constant 2000 dollars) & $\begin{array}{l}-1.483 \\
(-0.64)\end{array}$ & $\begin{array}{l}-2.027 \\
(-0.65)\end{array}$ \\
\hline Per capita GDP squared & $\begin{array}{r}0.007 \\
(0.05)\end{array}$ & $\begin{array}{r}0.044 \\
(0.20)\end{array}$ \\
\hline Gini coefficient in labor-sending country & $\begin{array}{l}0.955 \\
(0.77)\end{array}$ & $\begin{array}{l}0.743 \\
(0.51)\end{array}$ \\
\hline Real interest rate (percent) in labor-sending country & $\begin{array}{l}0.105 \\
(0.60)\end{array}$ & $\begin{array}{l}0.141 \\
(0.73)\end{array}$ \\
\hline Cost to send $\$ 200$ remittances to country & $\begin{array}{l}0.401 \\
(0.63)\end{array}$ & $\begin{array}{l}0.971 \\
(1.39)\end{array}$ \\
\hline Exchange rate spread in labor-sending country & $\begin{array}{l}-0.180 \\
(-2.18)^{*}\end{array}$ & $\begin{array}{l}-0.359 \\
(-3.97)^{* *}\end{array}$ \\
\hline War in labor-sending country (dummy) & $\begin{array}{l}0.295 \\
(0.91)\end{array}$ & $\begin{array}{l}0.608 \\
(1.85)\end{array}$ \\
\hline Constant & $\begin{array}{l}7.701 \\
(0.95)\end{array}$ & $\begin{array}{l}7.393 \\
(0.70)\end{array}$ \\
\hline $\mathrm{N}$ & 62 & 62 \\
\hline $\mathrm{R}^{2}$ & 0.839 & 0.829 \\
\hline F-statistic, excluded instruments & 52.58 & 39.64 \\
\hline P-value & 0.000 & 0.000 \\
\hline
\end{tabular}

Notes: All variables expressed in logs; all equations include 5 regional dummy variables which are not reported here. Robust t-statistics shown in parentheses. Number of observations reduced in table because of missing values for certain variables. See Appendix Table 1 for countries and survey dates.

* Significant at the 0.05 level $\quad * *$ Significant at the 0.01 level 
Table 4. IV estimates of effects of low-skilled migration (less than 8 years of schooling) on receipt of international remittances

\begin{tabular}{|c|c|c|c|c|c|c|}
\hline \multirow{2}{*}{$\begin{array}{l}\text { Variable } \\
\text { Instrumented endogenous variables }\end{array}$} & $(1)$ & $\begin{array}{l}\text { endent varia } \\
(2)\end{array}$ & $\begin{array}{l}\text { ta internati } \\
(3)\end{array}$ & $\begin{array}{l}\text { aces receive } \\
(4)\end{array}$ & $\begin{array}{l}\text { sending cot } \\
(5)\end{array}$ & $(6)$ \\
\hline & & & & & & \\
\hline $\begin{array}{l}\text { Percent of low-skilled migrants (less than } 8 \text { years schooling) in } \\
\text { total migrants from labor-sending country in OECD }\end{array}$ & $\begin{array}{l}0.914 \\
(1.96)^{*}\end{array}$ & $\begin{array}{l}1.026 \\
(2.05)^{*}\end{array}$ & $\begin{array}{l}1.985 \\
(3.79)^{* *}\end{array}$ & $\begin{array}{l}1.949 \\
(3.99)^{* *}\end{array}$ & $\begin{array}{l}1.463 \\
(2.91)^{* *}\end{array}$ & $\begin{array}{l}1.487 \\
(3.04)^{* *}\end{array}$ \\
\hline Stock of total migrants from labor-sending country in OECD & $\begin{array}{l}0.193 \\
(1.55)\end{array}$ & 0.179 & $\begin{array}{r}0.185 \\
(0.90)\end{array}$ & $\begin{array}{l}0.201 \\
(1.03)\end{array}$ & $\begin{array}{r}0.146 \\
(1.02)\end{array}$ & $\begin{array}{l}0.139 \\
(0.97)\end{array}$ \\
\hline Poverty headcount in labor-sending country (\$1.08/person/day) & $\begin{array}{l}-0.497 \\
(-2.20)\end{array}$ & - & $\begin{array}{l}-0.465 \\
(-1.81)\end{array}$ & - & $\begin{array}{l}-0.498 \\
(-0.93)\end{array}$ & - \\
\hline Poverty gap in labor-sending country & - & $\begin{array}{l}-0.347 \\
(-1.74)\end{array}$ & - & $\begin{array}{l}-0.429 \\
(-1.89)\end{array}$ & - & $\begin{array}{l}-0.338 \\
(0.90)\end{array}$ \\
\hline Exogenous regressors & & & & & & \\
\hline Percent of population under 14 years in labor-sending country & $\begin{array}{l}3.336 \\
(2.09) *\end{array}$ & $\begin{array}{c}3.101 \\
(2.07)^{*}\end{array}$ & $\begin{array}{l}3.382 \\
(1.94)\end{array}$ & $\begin{array}{l}3.049 \\
(1.78)\end{array}$ & $\begin{array}{l}3.276 \\
(2.12)^{*}\end{array}$ & $\begin{array}{c}3.060 \\
(2.03)^{*}\end{array}$ \\
\hline Per capita GDP in labor-sending country (constant 2000 dollars) & $\begin{array}{l}7.009 \\
(2.27)^{*}\end{array}$ & $\begin{array}{c}7.042 \\
(2.18)^{*}\end{array}$ & $\begin{array}{l}-1.716 \\
(-0.56)\end{array}$ & $\begin{array}{l}-2.523 \\
(-0.80)\end{array}$ & $\begin{array}{l}6.898 \\
(2.19) *\end{array}$ & $\begin{array}{c}6.951 \\
(2.12)^{*}\end{array}$ \\
\hline Per capita GDP squared & $\begin{array}{c}-0.484 \\
(-2.17)^{*}\end{array}$ & $\begin{array}{c}-0.471 \\
(-2.04)^{*}\end{array}$ & $\begin{array}{l}0.143 \\
(0.65)\end{array}$ & $\begin{array}{l}0.207 \\
(0.91)\end{array}$ & $\begin{array}{c}-0.473 \\
(-2.06)^{*}\end{array}$ & $\begin{array}{l}-0.462 \\
(-1.93)\end{array}$ \\
\hline Gini coefficient in labor-sending country & $\begin{array}{c}-3.477 \\
(-2.24)^{*}\end{array}$ & $\begin{array}{c}-3.679 \\
(-2.44)^{*}\end{array}$ & $\begin{array}{l}-2.858 \\
(-1.23)\end{array}$ & $\begin{array}{l}-2.785 \\
(-1.18)\end{array}$ & $\begin{array}{c}-3.391 \\
(-1.98)^{*}\end{array}$ & $\begin{array}{c}-3.615 \\
(-2.29)^{*}\end{array}$ \\
\hline Real interest rate (percent) in labor-sending country & $\begin{array}{c}0.445 \\
(2.27)^{*}\end{array}$ & $\begin{array}{c}0.453 \\
(2.32)^{*}\end{array}$ & $\begin{array}{c}0.731 \\
(3.55)^{* *}\end{array}$ & $\begin{array}{c}0.725 \\
(3.57)^{* *}\end{array}$ & $\begin{array}{c}0.515 \\
(2.49)^{*}\end{array}$ & $\begin{array}{c}0.510 \\
(2.49)^{*}\end{array}$ \\
\hline Cost to send $\$ 200$ remittances to country & $\begin{array}{l}-1.318 \\
(-1.68)\end{array}$ & $\begin{array}{l}-1.204 \\
(-1.44)\end{array}$ & $\begin{array}{l}-1.117 \\
(-1.93)\end{array}$ & $\begin{array}{l}-0.871 \\
(-1.39)\end{array}$ & $\begin{array}{l}-1.468 \\
(-1.62)\end{array}$ & $\begin{array}{l}-1.339 \\
(-1.29)\end{array}$ \\
\hline Exchange rate spread in labor-sending country & $\begin{array}{l}-0.087 \\
(-0.48)\end{array}$ & $\begin{array}{l}-0.125 \\
(-0.61)\end{array}$ & $\begin{array}{l}-0.324 \\
(-1.80)\end{array}$ & $\begin{array}{l}-0.390 \\
(-1.94)\end{array}$ & $\begin{array}{l}-0.108 \\
(-0.56)\end{array}$ & $\begin{array}{l}-0.140 \\
(-0.66)\end{array}$ \\
\hline War in labor-sending country (dummy) & $\begin{array}{l}0.729 \\
(1.65)\end{array}$ & $\begin{array}{l}0.781 \\
(1.70)\end{array}$ & $\begin{array}{l}0.362 \\
(0.91)\end{array}$ & $\begin{array}{l}0.489 \\
(1.13)\end{array}$ & $\begin{array}{l}0.665 \\
(1.69)\end{array}$ & $\begin{array}{l}0.723 \\
(1.78)\end{array}$ \\
\hline Constant & $\begin{array}{l}-38.701 \\
(-3.53)^{* *}\end{array}$ & $\begin{array}{l}-40.048 \\
(-3.46)^{* *}\end{array}$ & $\begin{array}{c}-13.262 \\
(-1.20)\end{array}$ & $\begin{array}{c}-10.765 \\
(-0.93)\end{array}$ & $\begin{array}{l}-39.176 \\
(-3.46)^{* *}\end{array}$ & $\begin{array}{l}-40.511 \\
(-3.58)^{* *}\end{array}$ \\
\hline $\mathrm{N}$ & 62 & 62 & 53 & 53 & 62 & 62 \\
\hline Centered $\mathrm{R}^{2}$ & 0.533 & 0.525 & 0.591 & 0.592 & 0.544 & 0.532 \\
\hline F-statistic & 5.78 & 4.84 & 8.86 & 8.68 & 7.48 & 6.94 \\
\hline Instrument set & A & A & $\mathrm{B}$ & $\mathrm{B}$ & $\mathrm{C}$ & C \\
\hline Anderson LR-statistic (identification/IV relevance test) & 37.182 & 37.934 & 44.788 & 44.092 & 5.416 & 8.875 \\
\hline p-value for Anderson LR-statistic & 0.000 & 0.000 & 0.000 & 0.000 & 0.020 & 0.002 \\
\hline Hansen J-statistic (overidentification test) & 0.534 & 0.668 & 4.439 & 3.653 & n.a. & n.a. \\
\hline p-value for Hansen J-statistic & 0.465 & 0.413 & 0.109 & 0.161 & & \\
\hline
\end{tabular}

Notes: All variables expressed in logs; all equations include 5 regional dummy variables which are not reported here. Robust t-statistics shown in parentheses. Number of observations reduced in table because of missing values for certain variables. See Appendix Table 1 for countries and survey dates.

* Significant at the 0.05 level ** Significant at the 0.01 level

n.a. not applicable as equation is exactly identified Instrument Sets:
A: Distance, language
B: Total population, population density, percent urban population
C: Percent urban population 
Table 5. IV estimates of effects of high-skilled migration (13 years or more of schooling) on receipt of international remittances

(1)

Dependent variable $=$ Per capita international remittances received by labor-sending country

\begin{tabular}{|c|c|c|c|c|c|c|}
\hline Variable & $(1)$ & $(2)$ & (3) & (4) & (5) & (6) \\
\hline \multicolumn{7}{|l|}{ Instrumented endogenous variables } \\
\hline Percent of high-skilled migrants (13 years or more schooling) & -1.119 & -1.286 & -1.968 & -1.857 & -1.607 & -1.566 \\
\hline in total migrants from labor-sending country in OECD & $(-1.76)$ & $(-1.82)$ & $(-3.01)^{* *}$ & $(-2.89) * *$ & $(-3.18) * *$ & $(-3.14)^{* *}$ \\
\hline \multirow[t]{2}{*}{ Stock of total migrants from labor-sending country in OECD } & 0.128 & 0.101 & 0.214 & 0.223 & 0.069 & 0.067 \\
\hline & $(0.96)$ & $(0.73)$ & $(1.03)$ & $(1.13)$ & $(0.51)$ & $(0.49)$ \\
\hline Poverty headcount in labor-sending country ( $\$ 1.08 /$ person/day) & $\begin{array}{l}-0.564 \\
(-2.68)^{* *}\end{array}$ & - & $\begin{array}{l}-0.607 \\
(-2.44)^{*}\end{array}$ & - & $\begin{array}{l}-0.671 \\
(-1.36)\end{array}$ & - \\
\hline Poverty gap in labor-sending country & - & $\begin{array}{c}-0.401 \\
(-2.09)^{*}\end{array}$ & - & $\begin{array}{c}-0.513 \\
(-2.27)^{*}\end{array}$ & - & $\begin{array}{l}-0.466 \\
(-1.33)\end{array}$ \\
\hline \multicolumn{7}{|l|}{ Exogenous regressors } \\
\hline \multirow[t]{2}{*}{ Percent of population under 14 years in labor-sending country } & 3.073 & 2.761 & 3.122 & 2.754 & 2.893 & 2.607 \\
\hline & $(2.10)^{*}$ & $(2.08) *$ & $(2.06)^{*}$ & $(1.85)$ & $(2.02)^{*}$ & $(1.90)$ \\
\hline \multirow{2}{*}{$\begin{array}{l}\text { Per capita GDP in labor-sending country (constant } 2000 \\
\text { dollars) }\end{array}$} & 7.078 & 7.126 & -1.661 & -2.471 & 7.012 & 7.092 \\
\hline & $(2.35)^{*}$ & $(2.26)^{*}$ & $(-0.58)$ & $(-0.82)$ & $(2.30)^{*}$ & $(2.22)^{*}$ \\
\hline \multirow[t]{2}{*}{ Per capita GDP squared } & -0.500 & -0.489 & 0.110 & 0.180 & -0.506 & -0.492 \\
\hline & $(-2.32)^{*}$ & $(-2.17)^{*}$ & $(0.53)$ & $(0.84)$ & $(-2.32)^{*}$ & $(-2.13)^{*}$ \\
\hline \multirow[t]{2}{*}{ Gini coefficient in labor-sending country } & -3.768 & -4.044 & -3.230 & -3.277 & -3.753 & -4.043 \\
\hline & $(-2.34)^{*}$ & $(-2.57)^{*}$ & $(-1.27)$ & $(-1.28)$ & $(-2.16)^{*}$ & $(-2.48)^{*}$ \\
\hline \multirow[t]{2}{*}{ Real interest rate (percent) in labor-sending country } & 0.416 & 0.421 & 0.654 & 0.643 & 0.458 & 0.446 \\
\hline & $(2.19)^{*}$ & $(2.22)^{*}$ & $(3.38) * *$ & $(3.32)^{* *}$ & $(2.37)^{*}$ & $(2.36)^{*}$ \\
\hline \multirow[t]{2}{*}{ Cost to send $\$ 200$ remittances to country } & -1.501 & -1.398 & -1.363 & -1.056 & -1.654 & -1.444 \\
\hline & $(-1.84)$ & $(-1.63)$ & $(-2.37)^{*}$ & $(-1.70)$ & $(-1.93)$ & $(-1.46)$ \\
\hline \multirow[t]{2}{*}{ Exchange rate spread in labor-sending country } & -0.090 & -0.134 & -0.326 & -0.388 & -0.118 & -0.162 \\
\hline & $(-0.50)$ & $(-0.66)$ & $(-1.83)$ & $(-1.93)$ & $(-0.62)$ & $(-0.77)$ \\
\hline \multirow{2}{*}{ War in labor-sending country (dummy) } & 0.714 & 0.771 & 0.166 & 0.341 & 0.675 & 0.768 \\
\hline & $(1.62)$ & $(1.68)$ & $(0.41)$ & $(0.75)$ & $(1.71)$ & $(1.93)$ \\
\hline \multirow[t]{2}{*}{ Constant } & -29.068 & -29.195 & 3.308 & 4.711 & -24.671 & -26.677 \\
\hline & $(-2.58)^{*}$ & $(-2.47)^{*}$ & $(0.29)$ & $(0.39)$ & $(-2.00)^{*}$ & $(-2.22)^{*}$ \\
\hline $\mathrm{N}$ & 62 & 62 & 53 & 53 & 62 & 62 \\
\hline Centered $\mathrm{R}^{2}$ & 0.541 & 0.529 & 0.589 & 0.580 & 0.547 & 0.531 \\
\hline F-statistic & 5.93 & 4.77 & 8.66 & 7.79 & 6.50 & 6.14 \\
\hline Instrument set & A & A & $\mathrm{B}$ & $\mathrm{B}$ & $\mathrm{C}$ & $\mathrm{C}$ \\
\hline Anderson LR-statistic (identification/IV relevance test) & 33.013 & 32.383 & 50.923 & 49.740 & 6.177 & 9.656 \\
\hline p-value for Anderson LR-statistic & 0.000 & 0.000 & 0.000 & 0.000 & 0.013 & 0.001 \\
\hline Hansen J-statistic (overidentification test) & 0.178 & 0.270 & 3.454 & 2.655 & n.a. & n.a. \\
\hline p-value for Hansen J-statistic & 0.673 & 0.603 & 0.178 & 0.265 & & \\
\hline
\end{tabular}

Notes: All variables expressed in logs; all equations include 5 regional dummy variables which are not reported here. Robust t-statistics shown in parentheses.

Number of observations reduced in table because of missing values for certain variables. See Appendix Table 1 for countries and survey dates.

* Significant at the 0.05 level ** Significant at the 0.01 level n.a. not applicable as equation is exactly identified

Instrument sets:
A: Distance, language
B: Total population, population density, percent urban population
C: Percent urban population 
Appendix Table 1. Summary of data on poverty, international remittances and skill composition of migrants

\begin{tabular}{|c|c|c|c|c|c|c|c|c|c|}
\hline Country & Survey Year & $\begin{array}{c}\text { Poverty } \\
\text { Headcount } \\
\text { (\$1/person/day) }\end{array}$ & $\begin{array}{r}\text { Poverty } \\
\text { Gap } \\
(\%) \\
\end{array}$ & $\begin{array}{r}\text { Gini } \\
\text { coefficient } \\
\end{array}$ & $\begin{array}{l}\text { International } \\
\text { Remittances } \\
\text { (million } \\
\text { dollars) }\end{array}$ & $\begin{array}{c}\text { Per Capita } \\
\text { International } \\
\text { Remittances } \\
\text { (dollars) }\end{array}$ & $\begin{array}{c}\text { Low- } \\
\text { skilled } \\
\text { Migrants } \\
\text { (\%) (Less } \\
\text { than } 8 \\
\text { years } \\
\text { schooling) }\end{array}$ & $\begin{array}{c}\text { High- } \\
\text { skilled } \\
\text { Migrants } \\
\text { (\%) (13 } \\
\text { years or } \\
\text { more } \\
\text { schooling) }\end{array}$ & $\begin{array}{c}\text { Population } \\
\text { under } 14 \\
\text { years (\%) }\end{array}$ \\
\hline Albania & 1996 & 0.62 & 0.07 & 0.291 & 499 & 151.2 & 46.2 & 18.4 & 30.1 \\
\hline Algeria & 1995 & 1.16 & 0.24 & 0.353 & 2460 & 80.6 & 76.7 & 14.1 & 34.1 \\
\hline Argentina & 1998 & 1.15 & 0.05 & 0.498 & 43 & 1.2 & 16.0 & 48.2 & 28.0 \\
\hline Armenia & 1998 & 4.98 & 1.09 & 0.36 & 10 & 2.6 & 18.0 & 47.0 & 25.9 \\
\hline Azerbaijan & 2001 & 3.67 & 0.63 & 0.365 & 104 & 12.8 & 25.9 & 49.9 & 31.0 \\
\hline Bangladesh & 2000 & 36.03 & 8.1 & 0.317 & 1958 & 15.1 & 41.3 & 36.3 & 37.5 \\
\hline Belarus & 2000 & 0.11 & 0.07 & 0.303 & 53 & 5.3 & 44.8 & 29.3 & 18.7 \\
\hline Bolivia & 1999 & 26.18 & 15.34 & 0.577 & 72 & 8.9 & 11.9 & 50.9 & 39.6 \\
\hline Brazil & 1999 & 8.01 & 1.88 & 0.591 & 1190 & 6.9 & 22.9 & 43.4 & 29.6 \\
\hline Bulgaria & 2001 & 3.02 & 0.59 & 0.343 & 421 & 51.7 & 52.8 & 16.4 & 15.7 \\
\hline Burkina Faso & 1998 & 44.85 & 14.42 & 0.468 & 62 & 5.8 & 57.7 & 30.1 & 48.4 \\
\hline Cambodia & 1997 & 34.08 & 9.68 & 0.403 & 10 & 0.9 & 48.5 & 25.7 & 40.7 \\
\hline Chile & 2000 & 0.97 & 0.18 & 0.576 & 395 & 25.6 & 16.9 & 47.4 & 27.8 \\
\hline China & 1999 & 0.46 & 0.14 & 0.315 & 21,283 & 16.8 & 29.7 & 48.0 & 24.8 \\
\hline Colombia & 2000 & 8.68 & 3.42 & 0.575 & 1578 & 37.4 & 16.6 & 41.7 & 32.8 \\
\hline Costa Rica & 2000 & 2.01 & 0.66 & 0.466 & 120 & 30.7 & 16.9 & 45.0 & 31.7 \\
\hline Cote d'Ivoire & 1998 & 15.53 & 3.82 & 0.437 & 49 & 3.2 & 47.6 & 30.7 & 43.3 \\
\hline Croatia & 2000 & 0.09 & 0.06 & 0.313 & 536 & 121.8 & 54.2 & 20.5 & 17.0 \\
\hline $\begin{array}{l}\text { Czech Republic } \\
\text { Dominican }\end{array}$ & 1996 & 0.12 & 0.12 & 0.258 & 452 & 43.8 & 39.4 & 33.1 & 16.4 \\
\hline Republic & 2000 & 1.09 & 0.19 & 0.521 & 1689 & 203.4 & 30.8 & 26.5 & 35.0 \\
\hline Ecuador & 1998 & 15.78 & 6.32 & 0.535 & 794 & 65.1 & 25.4 & 28.0 & 34.4 \\
\hline Egypt & 1999 & 3.09 & 0.43 & 0.344 & 3235 & 49 & 18.3 & 58.9 & 35.9 \\
\hline El Salvador & 2000 & 18.94 & 8.54 & 0.519 & 1750 & 277.8 & 41.1 & 19.1 & 35.6 \\
\hline Estonia & 1998 & 0.08 & 0.02 & 0.376 & 0.1 & 0.1 & 32.0 & 40.1 & 18.0 \\
\hline Ethiopia & 2000 & 22.97 & 4.82 & 0.3 & 53 & 0.8 & 21.0 & 48.7 & 45.5 \\
\hline Gambia & 1998 & 27.07 & 9.04 & 0.502 & 8 & 6.1 & 51.4 & 20.4 & 41.2 \\
\hline Georgia & 2000 & 2.83 & 0.88 & 0.266 & 94 & 20 & 27 & 51.9 & 21.6 \\
\hline Ghana & 1998 & 40.51 & 15.06 & 0.407 & 29 & 1.6 & 24.9 & 44.1 & 41.2 \\
\hline Guatemala & 1998 & 7.89 & 1.59 & 0.558 & 456 & 42.2 & 47.5 & 19.0 & 44.1 \\
\hline Guyana & 1998 & 2.98 & 0.6 & 0.445 & 15 & 18.8 & 17.8 & 44.2 & 30.7 \\
\hline Haiti & 2001 & 52.92 & 26.88 & 0.595 & 578 & 73.1 & 19.7 & 39.0 & 40.5 \\
\hline
\end{tabular}


Appendix Table 1. Summary of data on poverty, international remittances and skill composition of migrants

\begin{tabular}{|c|c|c|c|c|c|c|c|c|c|}
\hline Country & Survey Year & $\begin{array}{c}\text { Poverty } \\
\text { Headcount } \\
\text { (\$1/person/day) }\end{array}$ & $\begin{array}{r}\text { Poverty } \\
\text { Gap } \\
(\%)\end{array}$ & $\begin{array}{r}\text { Gini } \\
\text { coefficient }\end{array}$ & $\begin{array}{l}\text { International } \\
\text { Remittances } \\
\text { (million } \\
\text { dollars) }\end{array}$ & $\begin{array}{c}\text { Per Capita } \\
\text { International } \\
\text { Remittances } \\
\text { (dollars) }\end{array}$ & $\begin{array}{c}\text { Low- } \\
\text { skilled } \\
\text { Migrants } \\
\text { (\%) (Less } \\
\text { than } 8 \\
\text { years } \\
\text { schooling) }\end{array}$ & $\begin{array}{l}\text { High- } \\
\text { skilled } \\
\text { Migrants } \\
\text { (\%) (13 } \\
\text { years or } \\
\text { more } \\
\text { schooling) }\end{array}$ & $\begin{array}{c}\text { Population } \\
\text { under } 14 \\
\text { years (\%) }\end{array}$ \\
\hline Honduras & 1999 & 20.74 & 7.45 & 0.562 & 320 & 50.8 & 36.3 & 23.8 & 41.7 \\
\hline Hungary & 1999 & 0.26 & 0.15 & 0.277 & 26 & 2.5 & 31.7 & 39.1 & 16.9 \\
\hline India & 1999 & 19.26 & 3.88 & 0.35 & 11,002 & 10.8 & 21.8 & 60.5 & 34.1 \\
\hline Indonesia & 2000 & 7.19 & 1.04 & 0.303 & 1190 & 5.7 & 28.8 & 46.3 & 30.2 \\
\hline Iran & 1998 & 0.26 & 0.04 & 0.441 & 500 & 8.1 & 17.0 & 58.5 & 35.2 \\
\hline Jamaica & 2000 & 0.41 & 0.06 & 0.388 & 789 & 303.4 & 19.5 & 42.8 & 33.0 \\
\hline Jordan & 1997 & 0.36 & 0.10 & 0.36 & 1665 & 370 & 16.4 & 55.6 & 39.3 \\
\hline Kazakhstan & 2001 & 0.11 & 0.02 & 0.313 & 81 & 5.4 & 34.3 & 49.2 & 27.5 \\
\hline Kenya & 1997 & 20.13 & 4.84 & 0.425 & 533 & 18.9 & 20.4 & 44.8 & 44.1 \\
\hline Kyrgyz Republic & 2000 & 1.97 & 0.21 & 0.302 & 43 & 8.7 & 34.7 & 52.7 & 34.8 \\
\hline Latvia & 1998 & 1.53 & 0.67 & 0.336 & 3 & 1.2 & 22.3 & 51.2 & 17.9 \\
\hline Lesotho & 1995 & 36.40 & 18.97 & 0.631 & 0.6 & 0.3 & 21.1 & 49.6 & 40.7 \\
\hline Lithuania & 2000 & 0.53 & 0.18 & 0.318 & 2 & 0.6 & 42.7 & 29.1 & 19.8 \\
\hline Macedonia & 2000 & 1.51 & 0.64 & 0.206 & 80.0 & 40.0 & 52.2 & 19.6 & 22.1 \\
\hline Madagascar & 1999 & 66.03 & 29.42 & 0.418 & 105 & 6.9 & 36.9 & 43.4 & 44.8 \\
\hline Malawi & 1997 & 41.66 & 14.75 & 0.503 & 0.7 & 0.1 & 24.6 & 43.2 & 46.2 \\
\hline Malaysia & 1997 & 0.17 & 0.02 & 0.491 & 987 & 42.9 & 17.6 & 59.2 & 33.7 \\
\hline Mali & 2001 & 36.35 & 11.86 & 0.4 & 82 & 7.1 & 81.2 & 10.9 & 48.2 \\
\hline Mexico & 2000 & 5.87 & 1.57 & 0.518 & 6573 & 67.1 & 48.2 & 14.4 & 33.7 \\
\hline Moldova & 1999 & 32.24 & 9.93 & 0.368 & 0.6 & 0.1 & 26.7 & 45.8 & 22.9 \\
\hline Mongolia & 1998 & 27.02 & 8.08 & 0.302 & 5.5 & 2.3 & 17.2 & 61.1 & 35.1 \\
\hline Morocco & 1998 & 0.56 & 0.08 & 0.394 & 2011 & 72.3 & 70.6 & 12.9 & 33.4 \\
\hline Nepal & 1995 & 34.42 & 8.96 & 0.376 & 44 & 2.1 & 19.4 & 47.2 & 40.9 \\
\hline Nicaragua & 1998 & 44.68 & 16.62 & 0.452 & 200 & 41.6 & 19.8 & 38.5 & 42.0 \\
\hline Nigeria & 1996 & 79.28 & 51.36 & 0.696 & 947 & 8.3 & 12.9 & 65.0 & 45.3 \\
\hline Pakistan & 1996 & 29.49 & 6.46 & 0.302 & 1284 & 10.2 & 38.9 & 38.6 & 41.3 \\
\hline Panama & 2000 & 7.2 & 2.28 & 0.565 & 16 & 5.5 & 6.7 & 57.7 & 31.9 \\
\hline Paraguay & 1999 & 14.86 & 6.8 & 0.568 & 148 & 27.9 & 25.7 & 45.6 & 39.6 \\
\hline Peru & 2000 & 18.07 & 9.14 & 0.498 & 718 & 27.6 & 14.4 & 46.9 & 34.5 \\
\hline
\end{tabular}


Appendix Table 1. Summary of data on poverty, international remittances and skill composition of migrants

\begin{tabular}{|c|c|c|c|c|c|c|c|c|c|}
\hline Country & Survey Year & $\begin{array}{c}\text { Poverty } \\
\text { Headcount } \\
\text { (\$1/person/day) }\end{array}$ & $\begin{array}{r}\text { Poverty } \\
\text { Gap } \\
(\%)\end{array}$ & $\begin{array}{r}\text { Gini } \\
\text { coefficient }\end{array}$ & $\begin{array}{r}\text { International } \\
\text { Remittances } \\
\text { (million } \\
\text { dollars) }\end{array}$ & $\begin{array}{r}\text { Per Capita } \\
\text { International } \\
\text { Remittances } \\
\text { (dollars) }\end{array}$ & $\begin{array}{l}\text { Low- } \\
\text { skilled } \\
\text { Migrants } \\
\text { (\%) (Less } \\
\text { than } 8 \\
\text { years } \\
\text { schooling) }\end{array}$ & $\begin{array}{l}\text { High- } \\
\text { skilled } \\
\text { Migrants } \\
\text { (\%) (13 } \\
\text { years or } \\
\text { more } \\
\text { schooling) }\end{array}$ & $\begin{array}{c}\text { Population } \\
\text { under } 14 \\
\text { years (\%) }\end{array}$ \\
\hline Philippines & 2000 & 15.48 & 2.98 & 0.46 & 125 & 1.6 & 12.8 & 67.1 & 37.5 \\
\hline Poland & 2000 & 0.13 & 0.06 & 0.329 & 639 & 16.5 & 30.0 & 39.5 & 19.2 \\
\hline Romania & 2000 & 2.14 & 0.59 & 0.302 & 2 & 0.1 & 34.5 & 31.3 & 18.3 \\
\hline Russia & 2000 & 6.14 & 1.19 & 0.456 & 363 & 2.4 & 26.2 & 51.1 & 18.2 \\
\hline Slovak Republic & 1996 & 0.49 & 0.06 & 0.258 & 4 & 0.7 & 37.9 & 20.0 & 20.5 \\
\hline South Africa & 2000 & 10.71 & 1.74 & 0.577 & 38 & 0.8 & 10.8 & 62.6 & 33.5 \\
\hline Sri Lanka & 1999 & 7.58 & 1.49 & 0.332 & 1052 & 55.6 & 30.7 & 39.5 & 26.2 \\
\hline Tanzania & 2000 & 56.99 & 20.64 & 0.346 & 35 & 1.0 & 22.9 & 51.3 & 44.0 \\
\hline Thailand & 2000 & 1.93 & 0.05 & 0.431 & 867 & 14.1 & 28.9 & 44.6 & 25.6 \\
\hline Tunisia & 2000 & 0.32 & 0.07 & 0.408 & 796 & 82.9 & 73.0 & 14.9 & 30.2 \\
\hline Turkey & 2000 & 0.87 & 0.21 & 0.4 & 4560 & 67.6 & 79.1 & 8.8 & 30.7 \\
\hline Uganda & 1999 & 26.84 & 7.74 & 0.43 & 232 & 10.7 & 23.5 & 46.2 & 50.3 \\
\hline Ukraine & 1999 & 2.92 & 0.62 & 0.289 & 84 & 1.7 & 41.5 & 33.1 & 17.9 \\
\hline Venezuela & 2000 & 8.87 & 2.7 & 0.44 & 217 & 8.9 & 11.1 & 60.1 & 33.7 \\
\hline Vietnam & 1998 & 3.80 & 0.48 & 0.355 & 3200 & 40.7 & 28.5 & 40.0 & 33.5 \\
\hline Yemen & 1998 & 10.21 & 2.3 & 0.334 & 1202 & 72.8 & 33.7 & 34.5 & 48.3 \\
\hline
\end{tabular}

Notes: All poverty, inequality, income and remittance data from year of survey; all other data from 2000.

Sources: All poverty and inequality data from World Bank, Povcal Net. All remittance data (except as noted in endnote 3) from International Monetary Fund, Balance of Payments Statistics Yearbook. Data on skill composition of migrants from Docquier and Marfouk (2005), and population data from World Bank, Data Development Program (2006). 


\section{Notes}

${ }^{1}$ These figures for official international remittances do not include the large - and unknown - amount of international remittances which return to developing countries through unrecorded, informal channels.

${ }^{2}$ Recent works on the skill composition of migrants include Niimi and Ozden (2006) and Faini (2003, 2007). Faini (2007) appeared as this paper was going to press.

${ }^{3}$ Low-income and middle-income countries are those which are classified as such by the World Bank (2000, pp. 334-335). Lowincome countries are those with 1999 GNP per capita \$756 or less; middle-income countries are those with 1999 GNP per capita of \$756-\$9,265.

${ }^{4}$ Although the IMF data on international remittances include most countries, some countries do not report remittances data to the IMF. For example, in 2000 about 85 countries did not report any remittances data to the IMF; this list of countries includes at least 5 countries which are known to be large, labor-sending countries. For these 5 countries (Algeria, China, Gambia, Malaysia and Vietnam) remittances data are therefore taken from estimates made by the World Bank, Global Economic Prospects (2006: Table 4A.1.1).

${ }^{5}$ For a recent attempt to estimate the size of unrecorded, informal remittances in the developing world as a whole, see Freund and Spatafora (2005).

${ }^{6}$ For a full list of these 157 developing countries, see World Bank (2000, pp. 334-335).

${ }^{7}$ For the purposes of this study, OECD (Europe) includes 18 countries: Austria, Belgium, Czech Republic, Denmark, Finland, France, Germany, Hungary, Ireland, Italy, Luxemburg, Netherlands, Norway, Portugal, Spain, Sweden, Switzerland and United Kingdom. No migration data are available for Greece, Iceland, Poland, Slovak Republic and Turkey.

${ }^{8}$ It should also be noted that the Docquier and Marfouk (2005) data do not distinguish between permanent and temporary migrants; rather these data only count the total number of people who are "foreign born” and of working age living in the OECD.

${ }^{9}$ To ensure compatibility across countries, all of the poverty lines in Appendix Table 1 are international poverty lines, set at estimates of \$1.08 per person per day in 1993 purchasing power parity (PPP) exchange rates. The PPP exchange rates are used so that \$1.08 is worth roughly the same in all countries. PPP values are calculated by pricing a representative bundle of goods in each country and comparing the local cost of that bundle with the U.S. dollar cost of the same bundle. In calculating PPP values, the comparison of local costs with U.S. costs is done using conversion estimates produced by the World Bank.

${ }^{10}$ In this paper the terms “expenditure” and "income” are used interchangeably. 
${ }^{11}$ Data on per capita GDP income (constant 2000 US dollars) in this study come from World Bank, Development Data Platform (2006).

${ }^{12}$ One reviewer suggested that the level of education in the labor-sending country should also be included in the study. However, data on educational attainment are rather sparse for many developing countries, especially those in Sub-Saharan Africa. For example, adding information on educational attainment - such as percent of country population over age 25 with secondary school education (from Barro and Lee, 2000) - would have reduced the size of the data set from 76 to 38 countries.

${ }^{13}$ Data on population under 14 years of age and real interest rates come from World Bank, Development Data Platform (2006).

${ }^{14}$ Data on the costs of remitting US \$200 to a particular country come from the International Monetary Fund, Annual Report on Exchange Arrangements and Exchange Restrictions. Data on exchange rate spread come from Western Union, as reported in Freund and Spatafora (2005). Data on the presence of civil war are from Fearon and Laitin (2003).

${ }^{15}$ While such an instrumental variables approach is good for dealing with endogeneity, it is unable to control for the unobserved country characteristics that are likely to affect the receipt of remittances by a country.

${ }^{16}$ Ordinary least squares (OLS) estimates of equation (1) are available from the author upon request.

${ }^{17}$ One reviewer suggested that the level of income inequality (in a country) might also be endogenous in equation (1). However, three factors should be noted: (1) in most countries the level of income inequality (as measured by the Gini coefficient) changes very slowly over time; (2) recent studies of remittances and inequality which are based on large, nationally-representative household surveys have found that international remittances have only a small impact on the level of income inequality in a country (see Adams, 2004; Acosta et al 2006); and (3) in this data set, it proved impossible to identify suitable instrumental variables for income inequality. ${ }^{18}$ In this study distance between the labor-sending country and the main remittance-sending region (US, OECD (Europe) or Persian Gulf) is measured for each labor-sending country as the miles between the capital of that country and the main region from which it receives remittances. For example, for Latin American countries it is the distance to the United States, for North African countries it is the distance to OECD (Europe) and for South Asian countries it is distance to the Persian Gulf. For those countries (like Egypt and Jordan) which send migrant workers to both the OECD (Europe) and the Persian Gulf, the distance variable is calculated on the basis of where that country sends the largest proportion of its migrant workers.

${ }^{19}$ In this data set the simple correlation between the percent of urban population and the poverty headcount is -0.518 .

${ }^{20}$ Using a different data set and different assumptions, Adams (2006) also finds that an inverted U-shaped curve exists between the level of country income and the receipt of remittances. 
21 On this point, one reviewer noted that if high-skilled migrants remit less because they are more likely to stay in their newly adopted country, then the key variable is "duration of stay" rather than the skill level of migrants. Unfortunately, however, in this data set no information is available on the length of migrant stay in a country. 


\section{References}

Acosta, P., Calderon, C., Fajnzylber, P., and Lopez, H. (2006). "Remittances and development in Latin America.” World Economy, 29, 957-987.

Adams, Jr., R. (2004). “Remittances and poverty in Guatemala.” World Bank Policy Research Working Paper 3418. Washington, DC: World Bank.

Adams, Jr, R. (2006). “International remittances and the household: analysis and review of global evidence.” Journal of African Economies, 15, 396-425.

Adams, Jr., R. and Page, J. (2005). “Do international migration and remittances reduce poverty in developing countries?” World Development, 33, 1645-1669.

Agarwal, R. and Horowitz, A. (2002). “Are international remittances altruism or insurance: Evidence from Guyana using multiple-migrant households.” World Development, 30, 2033-2044.

Banerjee, B. (1984). “The probability, size and uses of remittances from urban to rural areas in India.” Journal of Development Economics, 16, 293-311.

Barro, R. and Lee, J. (2000). “Data set on educational attainment of the total population, aged 25 and older.” Available on the web site of the Center for International Development at Harvard University (www.ksg.harvard.edu/cid).

Cox, D., Eser, Z., Jimenez, E. (1998). “Motives for private transfers over the life cycle: An analytical framework and evidence for Peru.” Journal of Development Economics, 55, 57-80.

Docquier, F. and Marfouk, A. (2005). “International migration by education attainment, 1990-2000.” In International Migration, Remittances and the Brain Drain, eds. C. Ozden and M. Schiff (pp. 151-199). Washington, DC: World Bank.

El-Sakka, M. and McNabb, R. (1999). “The macroeconomic determinants of emigrant remittances.” World Development, 27, 1493-1502. 
Faini, R. (1994). “Workers remittances and the real exchange rate: A quantitative framework.” Journal of Population Economics, 7, 235-245.

Faini, R. (2003). “Is the brain drain an unmitigated blessing?” WIDER Discussion Paper 2003/64. Helsinki, Finland: World Institute for Development Economics Research.

Faini, R. (2006). “Remittances and the brain drain.” Centre for Economic Policy Research Working Paper 5720. London, England: Centre for Economic Policy Research.

Faini, R. (2007). “Remittances and the brain drain: Do more skilled migrants remit more?” World Bank Economic Review, 21, 177-191.

Fearon, J. and Laitin, D. (2003). “Additional tables for 'Ethnicity, Insurgency and Civil War.” Unpublished manuscript, Department of Political Science, Stanford University, Palo Alto, CA.

Foster, A. and Rosenzweig, M. (2001). “Imperfect commitment, altruism and the family: Evidence from transfer behavior in low-income rural areas.” The Review of Economics and Statistics, 83, 389-407. Freund, C. and Spatafora, N. (2005). “Remittances: Transaction costs, determinants and informal flows.” World Bank Policy Research Working Paper 3704. Washington, DC: World Bank.

Glytsos, N. (1997). “Remitting behavior of 'temporary’ and ‘permanent' migrants: The case of Greeks in Germany and Australia.” Labour, 11, 409-435.

Higgins, M., Hysenbegasi, A., Pozo, S. (2004). “Exchange-rate uncertainty and workers’ remittances.” Applied Financial Economics, 14, 403-411.

Ilahi, N. and Jafarey, S. (1999). “Guestworker migration, remittances and the extended family: Evidence from Pakistan.” Journal of Development Economics, 58, 485-512.

International Monetary Fund (various). Annual report of exchange arrangements and exchange restrictions. International Monetary Fund, Washington, DC.

International Monetary Fund (various). Balance of payments statistics yearbook. International Monetary Fund, Washington, DC. 
Lianos, T. (1997). “Factors determining migrant remittances: The case of Greece.” International Migration Review, 31, 72-87.

Lucas, R. and Stark, O. (1985). "Motivations to remit: Evidence from Botswana.” The Journal of Political Economy, 93, 901-918.

Niimi, Y. and Ozden, C. (2006). "Migration and remittances: causes and linkages.” Unpublished manuscript. World Bank, Washington, DC.

Passel, J., Capps, R., Fix, M. (2004). “Undocumented immigrants: facts and figures.” Unpublished manuscript. Urban Institute, Washington, DC.

Rapoport, H. and Docquier, F. (2004). “The Economics of migrants’ remittances.” Unpublished manuscript. Department of Economics, Bar-Ilan University, Israel.

Ratha, D. (2004). “Enhancing the developmental effect of workers’ remittances to developing countries.” In Global Development Finance (pp. 169-173). Washington, DC: World Bank.

World Bank (2000). World Development Report, 2000/01. World Bank, Washington, DC.

World Bank (2006). Development Data Platform database. World Bank, Washington, DC.

World Bank (2006). Global Economic Prospects. World Bank, Washington, DC.

World Bank (2006). Povcal Net database. World Bank, Washington, DC. 